\title{
Susbstance P Levels in Children with Atopic Dermatitis
}

\author{
Khairina Nasution', Deryne Anggia Paramita ${ }^{1}$ (D), Nova Zairina Lubis ${ }^{1}$ \\ ${ }^{1}$ Department of Dermatology and Venereology, Faculty of Medicine, Universitas Sumatera Utara, \\ Medan, Indonesia
}

\begin{abstract}
Background: Atopic dermatitis (AD) is the most common skin disease in infants and children. AD is influenced by hereditary and environmental factors, and it is characterized by an inflammatory reaction in the skin. In developing countries, children suffering from $\mathrm{AD}$ are estimated around $10-20 \%$, of which $60 \%$ of the cases persist into adulthood. Substance $\mathrm{P}$ is a cutaneous neuropeptide that contributes to the pathogenesis of AD. Substance P promotes the production of nerve growth factors from keratinocytes, and the release of histamine, leukotriene, or tumor necrosis factor from mast cells, which cause the growth of sensory nerve fibers, augmentation of skin inflammation, and are considered pruritogenic factors. Purpose: This study aims to determine the description of substance $\mathrm{P}$ in children with atopic dermatitis using a descriptive observational study with a cross-sectional approach. Methods: This is a destructive observational study with a crossectional approach samples were selected from AD patients at the Universitas Sumatera Utara Hospital. Result: The largest group of subjects were childhood (2-12 years old), there was $60 \%$, followed by the adolescent group (12-18 years old) and the infant group ( $<2$ years old). In the childhood group, the highest level of substance $\mathrm{P}$ was found in girls with a mean of $349.03 \pm 146.7$. On the other hand, the highest levels of substance $P$ in the adolescent were found in males with a mean of $243.73 \pm 64.57 \mathrm{ng} / \mathrm{L}$. Conclusion: In this study, we found that the level of substance $\mathrm{p}$ was higher in the childhood group.
\end{abstract}

Keywords: atopic dermatitis, substance P, children.

Correspondence: Deryne Anggia Paramita, Department of Dermatology and Venereology Faculty of Medicine Universitas Sumatera Utara, J1 dr T. Mansur no 66 Medan Indonesia. Phone: +6281361181386, e-mail: deryne.anggia@usu.ac.id.

Article info | Submited: 30-4-2021, Accepted: 8-6-2021, Published: 30-11-2021

\section{BACKGROUND}

Atopic dermatitis (AD) is a chronic inflammatory skin disorder that can impair quality of life, both through its symptoms and through secondary infections. Since the latter part of the last century, AD has increased and has become a significant clinical problem due to its prevalence, particularly in infants and young children. ${ }^{1,2}$ The prevalence of $\mathrm{AD}$ is estimated to be $15-20 \%$ in children and $1-3 \%$ in adults, and the incidence has in-creased by 2 - to 3 -fold during the past decades in industrialized countries. Study revealed that over $20 \%$ of children are af-fected by AD in some countries, but that the prevalence varies greatly throughout the world. ${ }^{3}$ The International Study of Asthma and Allergies in Childhood (ISSAC) found that the morbidity rate reached $20 \%$ in Asian countries such as South Korea, Taiwan, and Japan. ${ }^{4}$ In Indonesia, $\mathrm{AD}$ incidence was $11 \%$ among infants aged $0-4$ months. ${ }^{5}$

Atopic dermatitis is divided into three phases, namely the infant phase (age $<2$ years), the childhood phase (2-12 years), and the adult phase (12-18 years). In the infant phase, the signs of inflammation will appear at the age of three months. Inflammation often occurs in the flexural areas (childhood phase) and will go into remission by the age of 30 years. Meanwhile, in the adult phase, the AD onset begins during puberty. The reasons for the resurgence of inflammation are uncertain, but some theories suggested hormonal changes and stress levels in adolescence as factors. ${ }^{6}$

Atopic dermatitis involving skin barrier dysfunction and immune imbalance. Neuropeptides including neuropeptide $\mathrm{Y}$, substance $\mathrm{P}$, Calcitonin gene- related peptide exert their roles in $\mathrm{AD}$ lesions by regulating the function of inflammatory cells like $\mathrm{T}$ cells, mast cells and the release of inflammatory factors including IL- 1, TNF- $\alpha$. These inflammatory mediators, cytokines and vasoactive substances become important triggers of skin damage and itching production. ${ }^{7,8}$ The effects of substance $\mathrm{P}$ are largely mediated via Neurokinin 1 Receptor (NK1R), which can be found throughout the nervous system and peripheral tissues. Substance $\mathrm{P}$ is synthesized and released from mast cells, monocytes, and eosinophils in the skin. Along with IL-17A, Substance P appears to be significantly elevated in the plasma of AD patients. The percentages of substance $\mathrm{P}$ and NK1R represent elevated peripheral blood leukocytes in $\mathrm{AD}$ patients, and the amount of substance $P$ expressed by mast cells in skin lesions. ${ }^{9}$ Based on the explanation above, there is a link between substance $\mathrm{P}$ and $\mathrm{AD}$, but research on this field is still limited. 


\section{METHODS}

This cross-sectional study was conducted at the Polyclinic of the Division of Pediatric Dermatology Department Dermatology and Venereology, Universitas Sumatera Utara Hospital, Medan. Blood examinations were carried out at Prodia Laboratory. This research has been reviewed by the Ethics Committee at Universitas Sumatera Utara No. 92/KEP/USU/2020.

The study subjects were patients with AD diagnosed based on Hanifin and Rajka's criteria and willing to sign an informed consent. Potential study subjects were excluded if the parent/guardian cannot answer the questions provided or if the subject is suspected of having other skin or systemic diseases. Blood samples were collected to check substance P levels using the substance $P$ ELISA kit (R\&D Systems).

The sex and age distributions of study subjects are presented in a descriptive table. The distribution of children with $\mathrm{AD}$ and substance $\mathrm{P}$ levels were reported in mean values (median $\pm \mathrm{SD}$ ). Differences between the levels of substance $P$ in each age group, and also between subatance $\mathrm{P}$ level and sexes were tested using the Mann-Whitney test. Meanwhile, the correlation between age and substance $\mathrm{P}$ was tested with the Spearman correlation.

\section{RESULT}

There were 46 subjects include in this study. Table 1 shows the demographic characteristics of the study subjects. The proportion of the subjects was dominated by males (63\%). The largest group was the childhood group (2-12 years) with 28 participants, followed by the adolescent group (12-18 years) with 7 participants and the infant group ( $<2$ years) with 1 participant. The characteristics of the subjects based on age are divided into the childhood group (the infant group is combined with the childhood group) and the adolescent group. Male subjects were dominant in the two study groups, with 16 participants $(57.1 \%)$ in the childhood group and 12 participants $(70.6 \%)$ in the adolescent group. The mean age in the childhood group was $7.97 \pm 3.02$ years, with the youngest of 3 years old and the oldest of 12 years old. In the adolescent group, the mean age was $14.41 \pm 1.23$ years, with the youngest was 13 years old and the oldest was 17 years old.

Table 1. Demographic characteristics

\begin{tabular}{|c|c|c|c|c|}
\hline Characteristic & $\mathrm{n}=46$ & $\begin{array}{l}\text { Childhood } \\
(\mathrm{n}=29)\end{array}$ & $\begin{array}{c}\text { Adolescent } \\
(\mathrm{n}=17)\end{array}$ & $\mathrm{p}$ \\
\hline \multicolumn{5}{|l|}{ Sex, n (\%) } \\
\hline Male & $29(63 \%)$ & $17(58.6 \%)$ & $12(70.6 \%)$ & 0.417 \\
\hline Female & $17(37 \%)$ & $12(41.4 \%)$ & $5(29.4 \%)$ & \\
\hline \multicolumn{5}{|l|}{ Age, n $(\%)$} \\
\hline Infant (0-2 years) & $1(2.2 \%)$ & - & - & \\
\hline Childhood (2-12 years) & $28(60.9 \%)$ & - & - & - \\
\hline Adolescents (12-18 years) & $17(37 \%)$ & - & - & \\
\hline \multicolumn{5}{|l|}{ Age, years } \\
\hline Mean \pm SD & - & $7.97 \pm 3.02$ & $14.41 \pm 1.23$ & $<0.001$ \\
\hline Median (Min-Max) & - & $8(1-12)$ & $14(13-17)$ & \\
\hline
\end{tabular}

Table 2 presents data on the levels of substance $P$ in the childhood and adolescent groups. The mean level of substance $\mathrm{P}$ in the childhood group and adolescent group was $336.46 \pm 142.94 \mathrm{ng} / \mathrm{L}$ and $240.19 \pm 61.59$
ng/L, respectively. The Mann-Whitney test showed the differences in the level of substance $\mathrm{P}$ between childhood and adolescents groups $(I=95 \%, p=0.006)$.

Table 2. Difference in substance $P$

\begin{tabular}{llll}
\hline Substance P, ng/L & $\begin{array}{l}\text { Childhood } \\
(\mathrm{n}=29)\end{array}$ & $\begin{array}{l}\text { Adolescent } \\
(\mathrm{n}=17)\end{array}$ & $\mathrm{p}$ \\
\hline Mean \pm SD & $336.46 \pm 142.94$ & $240.19 \pm 61.59$ & 0.006 \\
Median (Min-Max) & $281.6(172.4-764.40)$ & $211.8(172.4-372.7)$ & \\
\hline
\end{tabular}

Note $: \mathrm{SD}=$ Standard Deviation 


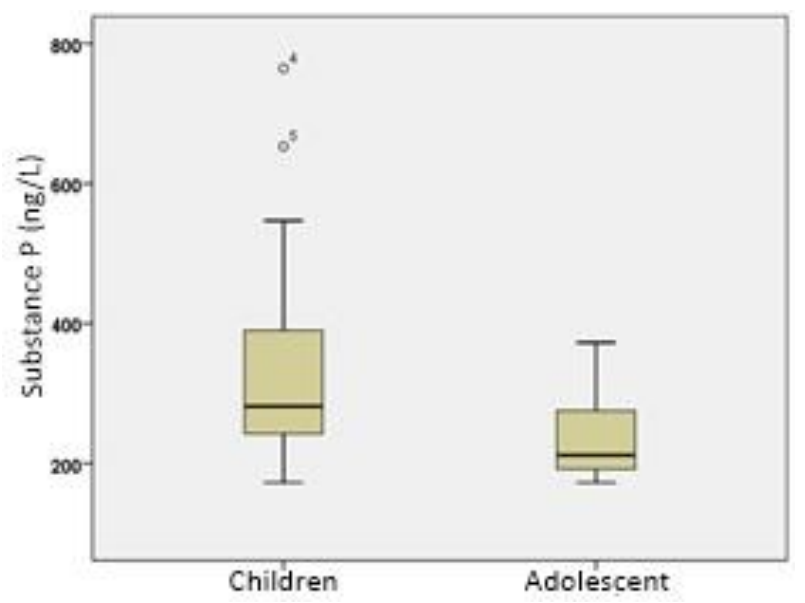

Figure 1. Boxplot graph of substance P levels in childhood and adolescent groups.

Tables 3 and 4 show the levels of substance $P$ were higher in female subjects with a mean of 349.03 based on sex of the two study groups. The level of $\pm 146.7 \mathrm{ng} / \mathrm{L}$. Using the Mann-Whitney test, there was substance $\mathrm{P}$ in the male adolescent group showed a no significant difference between the male and female mean of $327.59 \pm 144.07 \mathrm{ng} / \mathrm{L}$. The substance P levels subjects in the childhood group $(\mathrm{p}=0.616)$.

Table 3. Levels of substance $\mathrm{P}$ based on sex in the childhood group

\begin{tabular}{lll}
\hline Substance $\mathrm{P}, \mathrm{ng} / \mathrm{L}$ & Childhood $(\mathrm{n}=29)$ & $\mathrm{p}$ \\
\hline Male & 17 & $0.616^{*}$ \\
Mean \pm SD & $327.59 \pm 144.07$ & \\
Median (Min-Max) & $267.4(172.4-764.4)$ & \\
Female & 12 & \\
Mean \pm SD & $349.03 \pm 146.7$ & \\
Median (Min-Max) & $297(208.1-653)$ & \\
\hline
\end{tabular}

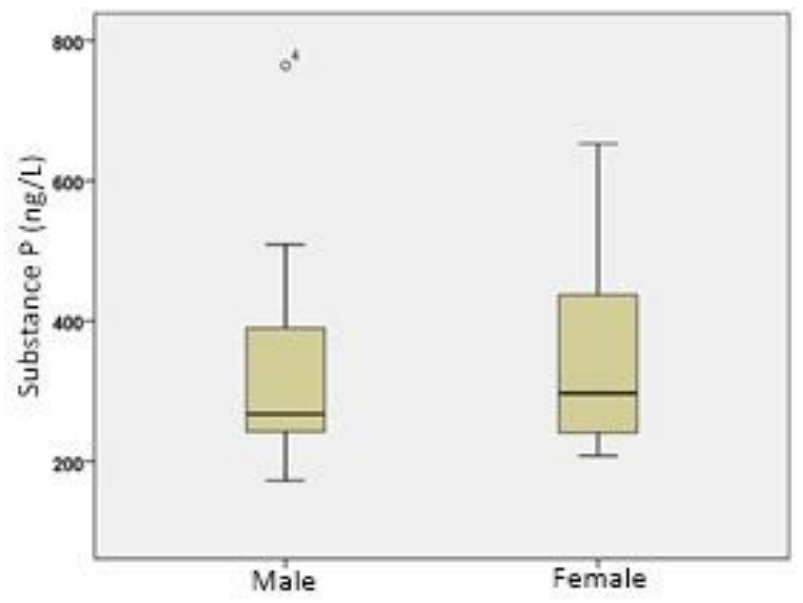

Figure 2. Boxplot graph of substance $P$ levels based on sex in childhood groups.

The level of substance $\mathrm{P}$ in the male and female adolescent group showed a mean of $243.73 \pm 64.57$ $\mathrm{ng} / \mathrm{L}$ and $231.72 \pm 59.82 \mathrm{ng} / \mathrm{L}$, respectively. There was no significant difference between male and female subjects in the adult group $(\mathrm{p}=0.727)$.
Table 5 shows the correlation between age and substance $\mathrm{P}$ levels in the two study groups. There was no significant correlation between age and substance $P$ levels in the childhood and adolescent groups ( $p>$ $0.05)$. 
Table 4. Levels of substance $P$ based on sex in the adolescent group

\begin{tabular}{lll}
\hline Substance P, ng/L & Adolescent $(\mathrm{n}=17)$ & $\mathrm{p}$ \\
\hline Male & 12 & \\
Mean \pm SD & $243.73 \pm 64.57$ & 0.727 \\
Median (Min-Max) & $212.4(172.4-372.4)$ & \\
Female & 5 \\
Mean \pm SD & $231.72 \pm 59.82$ & \\
Median (Min-Max) & $203.3(177.6-314.2)$ & \\
\hline
\end{tabular}

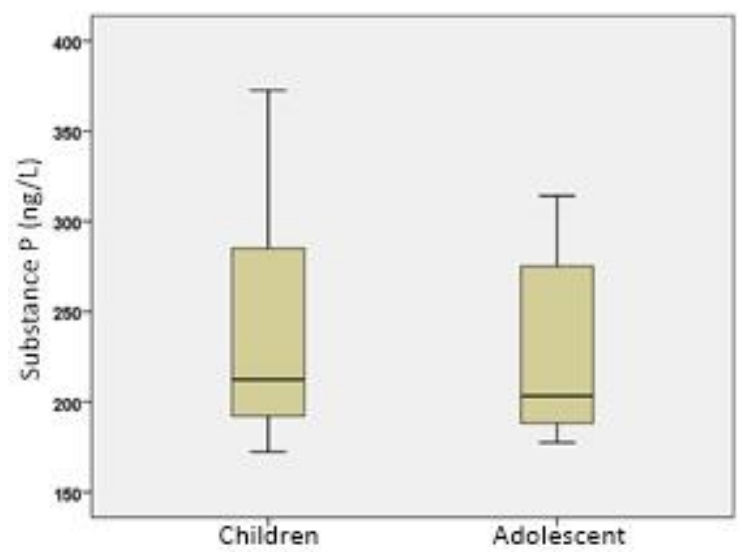

Figure 3. Boxplot graph of substance P levels by sex in adolescent groups.

Table 5. Correlation of age and substance $\mathrm{P}$ levels

\begin{tabular}{lllll} 
& & & \multicolumn{2}{l}{ Substance P } \\
\cline { 3 - 4 } & & $\mathrm{n}$ & $\mathrm{r}$ & $\mathrm{p}$ \\
\hline \multirow{2}{*}{ Age } & Childhood & 29 & -0.140 & 0.469 \\
& Adolescent & 17 & 0.358 & 0.158 \\
\hline
\end{tabular}

\section{DISCUSSION}

Atopic dermatitis (AD) is the most common skin disease found in infants and children. About $20 \%$ of the population in developing countries suffer from AD. The incidence of AD has tended to increase 2-3 times in the last 30 years. ${ }^{3}$

Most of the study subjects were males (63\%). This inline with previous research in China, in which males were reported more likely to suffer from AD, $54 \%$ of the subjects were males. ${ }^{10}$ However, it contradicts a questionnaire-based study conducted in Singapore involving 12,323 children aged 7,12 , and 16. The study reported no difference in the prevalence of atopic dermatitis based on sex. Likewise, several population-based studies in the United States specified that there was no relationship between gender and atopic dermatitis. ${ }^{11,12}$

The largest group of subjects were childhood aged 2-12 years old $(60.8 \%)$, followed by the adolescent group aged $12-18$ years old $(37 \%)$, and the infants ( $<2$ years) with $2.2 \%$. These result are in line with research by Ziyab et al., in which the proportion of two and four years old subjects suffering from AD was $16.8 \%$ and $10.9 \%$, respectively. Another research supports this study. It was conducted at the Children's Dermatology Division Outpatient Unit in Surabaya found that the average age of subjects with $\mathrm{AD}$ was 5.85 years $(\mathrm{SD}=4.13)$, with the youngest patient aged three months and the oldest was 13 years old. ${ }^{13,14}$

Several studies have shown that neuropeptides play an important role in the pathophysiology of pruritus in various skin diseases. Studies also found that the increase of substance $\mathrm{P}$ is due to the upregulation of the tachykinesia system in the skin of patients with inflammatory atopic dermatitis. ${ }^{15}$ Pruritus is a significant symptom of AD. Studies investigating the mechanisms of pruritus in humans and mice have reported substance $\mathrm{P}$ to be an important mediator of this symptom. Furthermore, substance $\mathrm{P}$ has been shown to induce wheal, flare and itching, when injected into human skin. ${ }^{16}$ Plasma levels of substance $P$ are elevated in $\mathrm{AD}$ patients and remain high even after remission in AD. This further induces the release of IFN- $\gamma$, IL-4, TNF- $\alpha$, and IL-10 from peripheral blood mononuclear 
leukocytes. ${ }^{17}$ This study found that females with higher substance $\mathrm{P}$ levels were in the childhood group 349.03 $\pm 146.7 \mathrm{ng} / \mathrm{L}$, while males were in the adolescent group $243.73 \pm 64.57 \mathrm{ng} / \mathrm{L}$. The statistical analysis also showed no relationship between sex and substance $\mathrm{P}$ levels in the childhood and adolescents groups $(p>0.05)$. To date, there are still limited studies that compare the levels of substance $\mathrm{P}$ based on sex in AD sufferers. Based on the result, there was no significant relationship between age and the level of substance $P$ in $A D$ patients $(p>0.05)$. This is in line with research by Kim et al., where they explained that the serum levels of substance $P$ varied widely in atopic dermatitis patients. Kim et al. found that 8 years old patients have a substance $P$ level of $27.8 \mathrm{ng} / \mathrm{L}$, patients aged 15 years had $16.9 \mathrm{ng} / \mathrm{L}$, and $29.2 \mathrm{ng} / \mathrm{L}$ in 18 years old patients. The varying levels of substance $\mathrm{p}$ indicate no relationship between substance $\mathrm{P}$ and age in the study. ${ }^{18}$ Toyoda also found that substance $\mathrm{P}$ levels were higher in $\mathrm{AD}$ patients with a mean age of 24 years than the control group, with $521.1 \mathrm{ng} / \mathrm{L} .{ }^{19}$ However, in a study conducted on $\mathrm{AD}$ patients with a mean age of 11 years, the substance P level obtained was $94.2 \mathrm{ng} / \mathrm{L}{ }^{20}$ The limitations of this study are the small number of subjects and limited age range.

\section{REFERENCES}

1. Dharmage, S.C. Lowe A. Matheson M. et al. Atopic dermatitis and the atopic march revisited. Allergy 2014; 69(1):17-27

2. Wang IJ, Wang JY, Yeh KW. Childhood Atopic Dermatitis in Taiwan. Pediatr Neonatol. 2016;57(2):89-96.

3. Nutten S. Atopic dermatitis: global epidemiology and risk factors. Ann Nutr Metab. 2015;66 Suppl 1:8-16.

4. Lawton S. Atopic eczema in children: NICE quality standard. Community practitioner : the journal of the Community Practitioners' \& Health Visitors' Association. 2013;86: 46.

5. Botteman, Marc F. Zakiudin M. Astrid W. et al. Economic value of atopic dermatitis prevention via partiallyhydrolyzed whey-based infant formula (PHF-W) use in high-risk, nonexclusively breastfed, indonesian urban infants: result of a cost-effectiveness model. World Nutrition Journal 2018. eISSN 2580-7013

6. Dinulos JGH. Habif's clinical dermatology. $7^{\text {th }}$ ed. Elsevier. 2021; 149-176

7. Zhang, Yue. Hanyi Z: Boyue current views on neuropeptides in atopic dermatitis. J. et al. Dermatol 2021;30:1588-97

8. Leung D.Y.M. New insights into atopic dermatitis: Role of skin barrier and immune dysregulation. Allergology International 2013;62:151161

9. Lotts, Tobias, Ständer, Sonja. Research in practice: Substance $\mathrm{p}$ antagonism in chronic pruritus. J Dtsch Dermatol 2014;12(7): 557-9

10. Wang X, Shi XD, Li LF, Zhou P, Shen YW, Song QK. Prevalence and clinical features of adult atopic dermatitis in tertiary hospitals of China. Medicine. 2017;96(11):e6317.

11. Tay YK, Kong KH, Khoo L, et al. The prevalence and descriptive epidemiology of atopic dermatitis in Singapore school children. Br J Dermatol 2002; 146:101-6.

12. Shaw TE, Currie GP, Koudelka CW, et al. Eczema prevalence in the United States: data from the 2003 national survey of children's health. J Invest Dermatol 2011; 131:67-73

13. Ziyab AH, Raza A, Karmaus W, et al. Trends in eczema in the first 18 years of life: result from the Isle of wight 1989 birth cohort study. Clin Exp Allergy 2010;40:1776-84.

14. Prameswari R, Astari L, Hidayati AN, Prakoeswa CRS. Efek lactobacillus plantarum terhadap imunoglobulin E serum total dan indeks scoring atopic dermatitis (SCORAD) pasien dermatitis atopi anak. Berkala Ilmu Kesehatan Kulit dan Kelamin. 2017;29(2):91-7

15. Lonndahl L, Rasul A, Rahm SBL, Holst M, Johansson B, Nour HE. Tachykinin upregulation in atopic dermatitis. Immunopharmacol immunotoxicol 2018;41(1).

16. Lonndahl, Louise. Mikael H. Maria B. Substance $\mathrm{P}$ antagonist aprepitant shows no additive effect compared with standardized topical treatment alone in patients with atopic dermatitis. Acta Derm Venereol 2018; 98: 324-328.

17. Choi JE, Di Nardo A. Skin neurogenic inflammation. Semin Immunopathol 2018;40(3): 249-259.

18. Kim HO, Lee $\mathrm{CH}$, Ahn HK, Park CW. Effects of tacrolimus ointment on the expression of substance $P$, nerve growth factor, and neurotrophin-3 in atopic dermatitis. Int $\mathrm{J}$ Dermatology 2009; 48(4): 431-8.

19. Toyoda M, Nakamura M, Makino T, Hino T, Kagoura M, Morohashi M. Nerve growth factor and substance $\mathrm{P}$ are useful plasma markers of disease activity in atopic dermatitis. British $\mathrm{J}$ Dermatology 2002; 147(1): 71-9.

20. Hon KL, Lam MC, Wong KY, Leung TF, Ng PC. Pathophysiology of nocturnal scratching in childhood atopic dermatitis: The role of brainderrived neurotrophic factor and substance P. 